\title{
A reinvenção da cidade na selva
}

José de Souza Martins* https://orcid.org/0000-0001-8747-1937

Neste ensaio, trato resumidamente do processo de surgimento das novas cidades amazônicas, nos anos de 1970 e 1980, com base em extensa pesquisa de campo, na região definida na época como Amazônia Legal, que delimitava o território que poderia ser beneficiado pelos chamados incentivos fiscais do governo federal. Nesse período, novas cidades estavam nascendo no marco novo de um projeto de ocupação dos chamados espaços vazios, que não o eram, posto em prática pelo Estado brasileiro. Em boa parte envolvendo um novo padrão de sobreposição da frente de expansão pela frente pioneira, que eu havia observado em trabalho anterior ${ }^{1}$. Formas de ocupação territorial que envolvem temporalidades históricas que, no geral, sucedem-se, mas que podem coexistir, a que correspondem modos de vida peculiares e desencontrados, dotados de espacialidades concebidas e vividas a partir de lógicas não só diferentes, mas sobretudo opostas. Na superposição escondem um conflito violento entre os agentes das funções sociais da terra de trabalho e os agentes das funções econômicas da terra de negócio. Neste caso, a terra como renda territorial e como versão fundiária da reprodução ampliada do capital.

A proposta deste Dossiê trata de questões teóricas relativas às cidades constituídas e ao urbano já definido como tal, com problemas próprios de realidades sociais dessa ordem. Porém, no Brasil, aquele período foi o da expansão da fronteira interna, a

* Universidade de São Paulo, São Paulo, Brasil.

1. Sobre a distinção sociológica entre frente de expansão e frente pioneira, que aqui adoto, ver Martins (1975). 
maior do mundo, sobre territórios ocupados ou por povos indígenas ou por populações rústicas encurraladas entre territórios ainda de populações tribais e territórios já ocupados por empresas agropecuárias. Três mundos sociais completamente diversos e em conflito. Nestes dois últimos, as novas aglomerações amazônicas, não urbanas e urbanas, povoados rústicos com poucas funções urbanas meramente complementares e cidades.

Nesse sentido, de certo modo, este trabalho é um contraponto à proposta original do dossiê, pois trata do nascimento de cidades baseado na indefinição de uma nova territorialidade, diferente da que marcou, historicamente, o nascimento das cidades no Brasil. A pesquisa cobriu, portanto, do extremo leste ao extremo oeste da Amazônia, num cenário em que a circunstância completamente nova da relação homem-natureza impôs aos novos habitantes a invenção da nova cidade da última fronteira do mundo. Reação que é a referência de fundo da interpretação dialética, tanto a de Marx quanto a de Lefebvre.

Do mesmo modo, impôs a penosa descoberta do peculiar e diferente da natureza a ser "amansada", palavra que ouvi em vários pontos da região. Houve desapontamentos e desilusões decorrentes de uma natureza desconhecida, não só nas cidades, mas também no campo, na agricultura e na pecuária. A inundação da cidade planejada da Nova Marabá, no Pará, pela cheia do rio Itacaiúnas, foi um desses episódios. Outro foi o do desmoronamento do bosque que separava a área comercial da área residencial da cidade de Nova Ariquemes, em Rondônia. A faixa fina de solo não suportou a mata nativa quando o entorno de sua sustentação foi abatido para abertura das ruas e construção de casas e edifícios. Na pecuária, a devastação da floresta para a abertura da Fazenda Suyá-Missú, no Mato Grosso, e formação das pastagens, expôs um terreno arenoso, o pasto mirrado e sua ocupação pelo gado limitado a índices de baixa ocupação. A natureza convulsionada foi a mediação da historicidade no nascimento da cidade na selva, nesse período.

Embora alguns aspectos da sociologia de Henri Lefebvre aplicada ao tema da cidade, do espaço e do urbano, sobretudo de seu método, sejam aplicáveis a um tema assim singularíssimo, há outros aspectos do tema que nunca foram considerados em perspectiva lefebvriana nem em perspectiva marxiana. Em Lefebvre, as contradições que propõem a cidade como o locus da historicidade contemporânea e a própria natureza como natureza-segunda, a nova natureza gerada pelo desenvolvimento capitalista e urbano, são contradições propriamente urbanas, a cidade como cadinho das tensões do repetitivo e do inovador, do possível.

Sem exagerar no que poderia ser considerado o "recorte amazônico" da questão, como se fosse um "mundo em si", na Amazônia as condições da historicidade, naquele período, propuseram-se como condições sociais e políticas da margem da 
sociedade capitalista, de uma sociedade inacabada, se a considerarmos a partir do pressuposto metodológico da totalização em curso. Isso porque as contradições que alcançam a Amazônia lhe são externas, estão em outro lugar, são-lhe determinações mediadoras cujo eixo está situado na reprodução ampliada do capital, e não no território virginal de um mundo que apenas nasce. É que ela nasce nos vazios do mundo já nascido, já determinado historicamente.

A terra, na qualidade de renda territorial capitalizada, e não como mera natureza, define suas novas funções históricas a partir do centro dinâmico do capitalismo e da reprodução ampliada do capital, funções que ela não tinha na fase pré-moderna das sociedades tribais e das frentes de expansão residuais. É onde está o núcleo dinâmico da dimensão especulativa do capitalismo brasileiro, que se nutre, quanto a isso, e nesse momento, menos da exploração do trabalho e muito mais da grilagem de terras e do planejamento estatal do uso das terras devolutas, ainda que já possuídas por posseiros, pequenos extrativistas e pequenos agricultores. A ocupação da Amazônia nos anos de 1970 e 1980 é a ocupação determinada por uma poderosa variante irracional e especulativa da acumulação do capital.

As novas cidades que nasceram na Amazônia, no período aqui indicado, não foram estruturadas com base na conflitividade própria da cidade lefebvriana, mas sim com base no entorno dominante, o dos pressupostos do caráter especulativo da renda fundiária como fundamento de um urbano gestado de fora para dentro. Menos porque fosse outra realidade e outra sociedade, diferente da industrialização socialmente transformadora, pressuposta por Lefebvre para pensar a cidade, e sim porque diferente da Europa de referência do desenvolvimento capitalista. O capitalismo brasileiro se constituiu através de um poderoso consórcio histórico entre terra e capital. Na Europa, a questão fundiária foi constituída pela função irracional da renda da terra pré-capitalista no desenvolvimento do capital, o capital como superação e inimigo histórico da renda territorial. Aqui, a renda da terra como sucedâneo da acumulação primitiva de capital, como reserva de valor e, em boa parte, fonte originária do capital.

A Amazônia dos anos de 1970 e 1980, tornou-se o último e dramático episódio dessa singularização do capitalismo. Portanto, as cidades da selva nasceram dominadas por essa poderosa mediação, a outra e oposta ponta do desenvolvimento das cidades, a datação do retrógrado, sem a qual não pode ele ser compreendido sociologicamente. Aí, sim, o recurso a Lefebvre é essencial, no campo metodológico: numa situação social que contém um "a mais" e diferente em relação à análise lefebvriana das cidades. Formaram-se as cidades, mas não se constituiu o propriamente urbano.

$\mathrm{E}$, ainda assim, com subdataçôes, como veremos aqui, no que se distinguem as cidades da Amazônia Ocidental e as da Amazônia Oriental. Entre Ariquemes, em 
Rondônia, e São Pedro da Água Branca, na Pré-Amazônia Maranhense, há uma distância sociológica maior do que entre São Félix do Araguaia, no Mato Grosso, e Recife, São Paulo, Rio de Janeiro ou Porto Alegre. Na Amazônia, as determinações sociais e históricas antiurbanas da formação das cidades, no período, definem fatores singulares para a compreensão sociológica das cidades da região. E, também, para ampliar o alcance da teoria lefebvriana da cidade e do urbano.

É nesse sentido que o cenário típico da Amazônia, na época, o do conflito entre terra e capital, entre rentismo e capitalismo, encerra dois diferentes possíveis, o de um e o de outro. A luta pela terra, na Amazônia, trazia consigo o anticapitalismo do uso comunitário da terra como bem comum e uma organização social baseada em códigos de relacionamento social dele derivados. Nos dois tipos de cidade, que menciono mais adiante, a cidade planejada e urbana, de feitio claramente capitalista, e a cidade evoluída do povoado e dos valores tradicionais e comunitários, dois caminhos de desenvolvimento urbano se propuseram e dois possíveis se apresentaram. Portanto, alternativas de historicidade opostas e cidades de funções históricas também opostas. Opostas porque uma marcada pela determinação da renda fundiária, a terra de negócio, como determinação constitutiva. Outra, porque apoiada numa concepção tradicional e comunitária do direito à terra de trabalho e, portanto, relativamente liberta da determinação social da renda da terra. Expressões de conduta social de populações socializadas em tradições diferentes e contrárias. $\mathrm{Na}$ primeira, as tensões e contradições do presente. Na segunda, as tensões são entre passado e presente, entre o tradicional e o moderno, o ontem que convive marginalmente com o atual.

Vista da perspectiva do Brasil capitalista e contemporâneo, a frente de expansão foi a representada pela espontânea ocupação de territórios, até então de perambulação razoavelmente demarcada de tribos indígenas ( Ribeiro, 1970), pelas populações residuais ou excluídas das áreas já ocupadas ou pela pecuária ou pela grande agricultura de exportação. "Empurradas" para o norte e para o oeste, por sua vez pressionaram as populações indígenas a avançarem na direção da cabeceira dos rios e a se refugiarem cada vez mais no interior do país. Ainda é possível encontrar tribos indígenas, não raro remanescentes de grupos de outras regiões, cujo deslocamento revela que viveram no litoral do Brasil na época da Conquista, fugitivas das expedições de caça ao índio. E, mais tarde, de sua redução e até de seu extermínio para "limpar" áreas buscadas pela grande lavoura.

Também os posseiros, na Amazônia muitos deles antigos seringueiros sem função em decorrência da ruína da economia da borracha a partir de 1910, foram sendo empurrados pela frente pioneira que se expandia em busca de terras novas para a pecuária e a agricultura comercial de grande escala. 
De vários modos, a fronteira tem sido o lugar da fuga e do refúgio para as populações que neste país continental descobriram-se sem território e sem terras, a multidão dos sem lugar. A forma de habitação e de convivência conhecida como cidade não fazia nem faz parte da cultura dessas populações de situações espacialmente temporárias e transitórias. Quando muito, têm elas no povoado rústico e espontâneo uma forma de agrupamento prenunciadora do que se pode chamar de urbano. Dominada, ainda, por técnicas, modos de vida e mentalidades que pertencem ao mundo pré-capitalista. Não é raro ver-se nesse território do limite, mesmo em povoados que rapidamente se transformaram em grandes cidades, pessoas desenvolvendo atividades artesanais sofisticadas, do remotamente período inaugural da indústria. Vi isso em Santa Teresinha e em Porto Alegre do Norte, no estado do Mato Grosso.

No Brasil, historicamente, essa privação de lugar tem tido a função de gerar uma superpopulação relativa de mão de obra sobrante. Mas essa política de produção de excedentes populacionais só tem sentido quando, na outra ponta do processo econômico, estão surgindo atividades carentes de mão de obra. Já nos anos de 1970, quando a política contemporânea de ocupação do território amazônico se robustece, também nessa outra ponta, cada vez mais, os excedentes populacionais cresceram em decorrência de transformações tecnológicas substitutivas de mão de obra. Não tem sido ele polo de atração e de inclusão produtiva desses excedentes, das populaçóes sobrantes geradas pelo modelo de desenvolvimento econômico que passou a regular a sociedade brasileira a partir do golpe de Estado de 1964.

As cidades amazônicas dessa nova onda de alargamento da fronteira econômica já nascem, portanto, num cenário antiurbano de problemas sociais. $\mathrm{O}$ fato de que essa fronteira seja marcada pelo renascimento do trabalho escravo na abertura de novas fazendas e de que, em várias de suas cidades, os linchamentos ocorram com frequência, não confirma tratar-se de cidades no sentido histórico, como lugares de emancipação dos seres humanos com relação ao retardamento pré-moderno do modo de vida.

Por outro lado, a cidade não foi nem é característica da frente de expansão. Quando muito, aqui e ali, por longo tempo, houve algumas concentrações urbanas muito dispersas, mero entrepostos, de funções comerciais simples. A frente de expansão é, sobretudo, um lugar de baixa vitalidade econômica, na qual, quando há cidade, é ela reduzida a funções urbanas mínimas e incompletas. Caso dos vários povoados aqui citados.

Já a frente pioneira tem sido a forma da ocupação territorial economicamente organizada, seja por empresas agrícolas, seja pela agricultura familiar e comercial. A cidade tem sido seu polo aglutinador, político, econômico, social e religioso. A frente pioneira tem sido entre nós, historicamente, disseminadora de cidades. A ideologia do pioneiro é a do plantador de cidades, como define Deffontaines (Deffontaines, 2004). 
No período em que eu fazia na região amazônica extensa pesquisa sobre os conflitos de fronteira, nos anos de 1970 e 1980 (Martins, 2014), a frente pioneira definiu a dinâmica da expansão territorial do capital e incorporou, transformando, áreas da frente de expansão, reduziu e confinou os territórios indígenas e ampliou a violência mediada pela lógica da renda da terra e do mercado. Sob a aparência de uma expansão da economia propriamente capitalista, a disseminação das novas cidades se deu como momento de um enredo conflitivo. Diferente do que é próprio da cidade, aqui não tem ela assumido plenamente a forma social positiva de disseminação e articulação dos meios de emancipação e humanização do homem nos novos territórios. Os fatores de emancipação humana colidem diariamente com os fatores e motivos de sua negação.

Têm sido elas também, e contraditoriamente, instrumentos de combate contra a resistência à espacialidade de um modelo peculiar de desenvolvimento econômico que abrange devastação ambiental e degradação social. Longe do que historicamente aconteceu em outros países, em que a cidade foi meio de civilidade, na Amazônia, a cidade foi e tem sido meio também de sua negação. Não é casual que, com frequência, ocorram episódios de barbárie nesse urbano mutilado.

Lembro aqui dois episódios envolvendo violento conflito entre colonos da frente pioneira e populações indígenas do estado de Rondônia, numa área já nucleada por cidades nascentes. De um lado, o caso da recíproca paixão de um adolescente da tribo Paíter, Oréia, e Orminda, também adolescente, filha de colonos capixabas então recém-chegados. Uma história shakespeariana na selva, em 1976. Como os pais da moça proibissem o namoro, Oréia a raptou e a levou para sua aldeia. Os colonos se organizaram, resgataram-na e os pais a deportaram de volta para seu estado de origem. Oréia entrou em profunda depressão, o que levou seu grupo de idade a atacar os colonos e a matar vários deles. Em resposta, os colonos contra-atacaram, mataram Oréia e o esquartejaram. Outro episódio foi o do sequestro de um adolescente, filho de colonos, pelos índios Uru-éu-uau-uau. A família do sequestrado e os assentados nas terras da região se organizaram e atacaram a tribo, em busca do jovem raptado. Nunca foi encontrado.

Conflitos característicos da frente de expansão que, no entanto, se manifestaram, também, na peculiar frente pioneira de Rondônia. Forçada pelas políticas territoriais e econômicas do governo militar, essa frente pioneira se antecipou à fase histórica do que até então havia sido característico de um processo compassado e lento de ocupação do território do país: o da frente de expansão.

No entanto, o que é próprio da frente de expansão não desapareceu completamente com a dinâmica mais intensa da frente pioneira, como esses casos mostram. Temporalidades, modos de vida e mentalidades historicamente desencontrados e 
diversamente datados não revestiram as cidades amazônicas, nessa fase, das características do que tende a ser propriamente o urbano, linear, unitemporal e racional. Índices de desconstrutividades sociologicamente explicativas são, de vários modos, por suas determinações históricas, o peculiar da cidade brasileira. Mesmo em São Paulo, esses desencontros estão fortemente presentes. O que, na perspectiva lefebvriana, pode constituir a referência empírica de uma possibilidade metodológica para nossa sociologia urbana.

Concebida a frente de expansão a partir do seu elemento constitutivo, a ausência da renda territorial convencional, da terra em si como equivalente de mercadoria, o povoamento baseado na concepção da terra de livre ocupação, sua personagem característica é a do posseiro. Algo que muito deve ao regime sesmarial, no período colonial, em que a posse útil precedia e validava o pedido de reconhecimento oficial do direito de uso. Poderemos, então, compreender que a fronteira, no período desta pesquisa, foi lugar de um grande cenário de conflito entre frente de expansão e frente pioneira. O que encerrou e encerra uma disputa sobre a própria concepção de ser humano, como ouvi de um menino claramente mestiço, em São Félix do Araguaia, à margem do rio. Interpelei-o porque ria de um índio karajá, que passava, cabisbaixo. Perguntei-lhe por que fazia aquilo, pois o índio era gente como ele e eu. Muito surpreso, respondeu-me que ele não era igual ao índio. $\mathrm{O}$ índio era gentio e ele era cristão. Linguagem da época colonial e da caça ao índio, em que só por meio do batismo católico o índio era reconhecido como gente.

Mesmo que a frente pioneira se baseie em princípios legais e tenha a sustentação das instituições, a frente de expansão tem se baseado na concepção paralela e alternativa de que a terra é de quem a ocupa e nela trabalha.

Encontrei, nessas áreas, não o dono da terra, o proprietário, mas o "dono do lugar", o primeiro a ocupá-lo, a pessoa que amansou a terra, tornou-a cultivável, habitável e lugar de convivência e coexistência, o fundamento do urbano. A ele os que vêm depois "devem" pedir licença para ocupá-la também. É ele senhor de um senhorio moral, o fundador de um lugar. Não lhe cabe nem a retribuição do pagamento nem a da prestação de serviços. Cabe-lhe apenas o respeito da precedência, não raro o conselheiro da forma de ocupação e uso da terra. Em alguns desses lugares, uma autoridade difusa, não raro personificada pelo "dono do lugar", estabelece o lugar ou lugares do banho coletivo diário, que separa lugar das mulheres e lugar dos homens, ou horário de umas e outros. Tudo sujeito a controle rigoroso e a punição severa em caso de transgressão, de que alguém decida, às escondidas, espiar o banho das mulheres.

Se na frente pioneira a compra da terra-mercadoria é a fonte da sua legalidade, na frente de expansão o trabalho que "amansa a terra" é que legitima sua posse. Essas duas concepções de direito têm persistido em nossa questão territorial.É sua diferença 
que regula a dinâmica e a forma que a ocupação de dada região acaba assumindo, o que interfere diretamente no tipo de evolução dos aglomerados populacionais, eventualmente sob a forma de cidade.

A frente de expansão não se manteve estagnada. Por via indireta, ela acabou alcançada pelos estímulos econômicos à expansão territorial do capital, preservando características de uma relação pré-moderna com a terra. Ainda que com limitações, a frente de expansão tendeu a se tornar, quando não alcançada pelo processo de modernização próprio da frente pioneira, cenário de uma espécie de capitalismo residual, limitado e incompleto, de desenvolvimento lento. Pode-se ver isso comparando localidades distantes entre si, surgidas na mesma época, na década de 1970, como cidades da frente de expansão e cidades da frente pioneira. É o caso de Santa Teresinha, no norte do Mato Grosso, e Ariquemes, em Rondônia.

Nesse período, na frente de expansão, houve tanto a disseminação de aglomerados espontâneos, os chamados povoados, por populações excedentes de áreas de ocupação tradicional, ou de áreas de antigos e decadentes seringais ou atraídas pela perspectiva do desenvolvimento econômico futuro, decorrente do deslocamento da frente pioneira na retaguarda. No geral, localidades sem edificações e obras próprias do que em nossa cultura se define como urbano: a escola e a igreja. Não obstante, muitos desses povoados, nos últimos trinta anos, tenham se tornado sede de municípios.

Alguns dos que conheci nos estados de Pará, Mato Grosso, no Maranhão tinham, em compensação, como equipamentos propriamente urbanos, ao menos um prostíbulo, um número grande de botecos, basicamente de venda de cachaça, e não pequeno número de "farmácias", verdadeiros botequins de remédios (ver Anexo: Ensaio visual). Eram os estabelecimentos públicos desses lugares, botecos e farmácias definindo o centro e o puteiro definindo a periferia. Eventualmente, "escolas" improvisadas em ranchos erguidos pela própria população, professores por ela pagos com o fornecimento da alimentação e do rancho da moradia.

Foi a minha pesquisa, solitária, parcialmente financiada pela Fundação de Amparo à Pesquisa do Estado de São Paulo (Fapesp), que cobriu da Pré-Amazônia maranhense ao Pará, ao Mato Grosso, a Goiás, a Rondônia, ao Acre². Para a compreensão que do assunto aqui proponho, polarizo dois grupos de experiências sociais opostas na gestação das cidades e do modo de vida urbano no cenário peculiar da suposta terra de ninguém. De um lado, a formação de cidades na Amazônia Oriental (maranhense, paraense, mato-grossense e goiana), e de outro, a formação de cidades na Amazônia Ocidental (rondoniana e acreana). Como tendências esquemáticas, entre as duas Amazônias desenhou-se uma linha nítida de separação territorial, dois modos de

2. Os principais resultados da pesquisa estão apresentados em Martins (2014). 
vida, dois modos de morar em grupo e de pensar (ver as legendas das fotografias no Anexo).

Num extremo, a formação espontânea, a partir do aparecimento de pequenos povoados, decorrente da ocupação da terra por migrantes oriundos, em grande parte, do semiárido do Nordeste. Ocupantes de terras que supunham devolutas, as chamadas terras livres, fora da espacialidade mediadora da renda territorial. Lugares como Ribeirão Cascalheira, Santa Teresinha e São Félix do Araguaia, no Mato Grosso, foram daqueles de mais intenso ativismo das pastorais sociais da Igreja Católica. Foi-o com base num imaginário que valorizava a pessoa e a comunidade, em boa parte inspirado nas ideias do personalismo de Emmanuel Mounier (1964), fundador da revista católica Esprit. Ação que foi uma das bases da formulação e difusão da Teologia da Libertação entre nós. De vários modos, imaginários anticapitalistas.

Santa Teresinha, no norte do estado e à beira do rio Araguaia, era um povoado antigo, em boa parte resultante do trabalho missionário católico, quase encravado em território indígena. Próxima, ficava a última aldeia dos índios tapirapé, quase exterminados pelos índios kayapó. Tensão que testemunhei. Numa manhã, da época de minha estada em Santa Teresinha, chegou a correr o boato de que um grupo de índios kayapó fora visto dirigindo-se à aldeia tapirapé para atacá-la. Passariam pelo povoado. O que gerou um dia inteiro de apreensão nos moradores. Lugar de um cotidiano de temores ainda dos tempos coloniais.

Localidade que foi cenário de uma disputa violenta entre duas concepçóes do urbano, nos anos de 1970. O povoado era um característico aglomerado da frente de expansão, quando a política de incentivos fiscais da Superintendência do Desenvolvimento da Amazônia (Sudam) levou à abertura de grandes fazendas de gado na região, uma delas, a Fazenda chamada Codeara (Companhia do Desenvolvimento do Araguaia), propriedade de um grande banco brasileiro.

Região povoada desde 1910-1915, paróquia desde 1964, o povoado foi objeto, por parte da empresa que se tornara formalmente proprietária da terra já ocupada, de uma tentativa de sobrepor-lhe um traçado urbano moderno. Os moradores, que eram posseiros, poderiam comprar da fazenda os lotes do novo desenho urbano, desse modo regularizando e legalizando em seu nome a propriedade do respectivo terreno. Em 2 de março de 1972, homens da fazenda tentaram derrubar a unidade de saúde mantida pela Igreja e construída pela população local para redesenhar o povoado como futura cidade. Houve reação armada dos moradores, o que culminou no reconhecimento do povoado tal qual era e no do direito de sua população às terras ocupadas.

Com o tempo, Santa Teresinha foi elevada a município, ganhou autonomia e acabou atraindo comerciantes. Foi, provavelmente, o mais significativo confronto entre 
duas concepções do urbano nessa fase de disputa de territorialidades na Amazônia. Com Lefebvre (1974), poderíamos defini-las como a do vivido e a do concebido, a do espontâneo e a do planejado. Diferente da teoria, entre o concebido e o vivido não havia mera relação de tensão, mero desenvolvimento desigual. Não eram níveis do urbano, mas urbanos opostos, um mais e outro menos urbano, projetos alternativos de vida em comum.

Encontrei, mesmo no âmago da Amazônia Ocidental da década de 1970, uma variante muito significativa de potenciais cidades originadas da ocupação espontânea da terra. Na orientação esquemática que estou adotando para compreender diferenças na concepção de cidade na região, é ela um exemplo singular dos efeitos urbanos do imaginário e da criatividade de uma sociabilidade de população de frente de expansão. Não muito longe de Rio Branco, capital do Acre, visitei uma ocupação que não hesitaria em definir como fundadora de cidade, pois se tratava de uma verdadeira cidade paralela à capital, improvisada às pressas, em extenso terreno baldio destinado pelo governo federal à implantação de um conjunto habitacional.

Tratava-se de mata atravessada por um caminho que levava a uma região de habitação dispersa. Uma prostituta, que atravessava o lugar todas as noites, para retornar a sua casa, foi ali assassinada. Era uma senhora conhecida de todos e por todos respeitada. Em diferentes pontos da Amazônia, em alguns dos quais fiz entrevistas com prostitutas, a prostituição é reconhecida como profissão de pessoas pobres, que não têm outro meio para sustentar a família. Com naturalidade, crianças que entrevistei em diferentes lugares, na pergunta sobre a o trabalho de cada membro da família, disseram que tal irmã "trabalhava de meretriz".

Uma multidão se formou ao redor do corpo, muitos comentando a violência e a injustiça daquele ato contra uma mulher vitimada pela pobreza. Mal o corpo foi removido pela polícia, a mata foi derrubada pelos moradores pobres da região. Num papel de embrulho, alguns desenharam, a lápis, o plano de uma cidade. No próprio local vi essa planta, que me foi mostrada por alguns dos que participaram da invasão. $\mathrm{O}$ exato lugar em que o corpo da vítima fora encontrado se tornou o centro de dois riscos em cruz e, portanto, o centro da cidade assim imaginada. A partir desses dois riscos, foram desenhados ruas transversais e lotes (Martins, 1998).

Por ocasião de minha visita, o terreno já estava quase todo demarcado. Os primeiros barracos começavam a ser construídos. Houve abusos de alguns ocupantes, especialmente dos que não participaram da comoção pela morte da mulher. Foi o caso da invasão de lotes já "outorgados" a participantes do movimento, e o caso dos que demarcaram mais de um lote com a intenção de vendê-los. Sobretudo, foi o caso dos que fizeram demarcação própria de lote em desacordo com a planta da localidade feita em comum pelos envolvidos no movimento. 
O caso dessa ocupação tem algumas indicações muito significativas de direito à terra urbana, com o explícito veto à renda territorial, isto é, à concepção mercantil de terra para negociar e não para morar. $\mathrm{O}$ valor de uso da terra contraposto $\mathrm{e}$ oposto ao seu potencial e suposto valor de troca. A mais significativa é a do direito à ocupação da terra pelos pobres em decorrência de ter sido ela "sacralizada" pelo sangue da vítima pobre, o sacrifício, a morte sacrificial como fonte de direito, esse sangue como tributo sagrado.

O desenho do aglomerado, modelado pela cruz de referência do traçado "urbano" e centralizado pelo exato local do derramamento de sangue inocente, confirma a natureza religiosa do imaginário de invenção dessa "cidade". Não se trata apenas de desenho, mas de fonte do direito e da forma e figuração de sua realização. Portanto, uma anticidade ou uma pré-cidade, e não mera ocupação individual da terra de moradia, porque ato coletivo. Mas celebração religiosa, invenção religiosa da cidade e invenção de uma religião da cidade. $\mathrm{O}$ todo como sujeito de invenção urbana.

Essa ocorrência encarta uma concepção tradicionalista de cidade e de ocupação da terra urbana no interior de uma região que estava toda ela destinada à agricultura moderna e à cidade moderna, caso dos estados de Rondônia e do Acre, e que não obstante viveu vários episódios de dissidência em relação ao tipo de ocupação territorial que o regime militar havia concebido para aquela área.

No extremo do modelo, na Amazônia Ocidental, o território foi sendo ocupado por migrantes do Sul do Brasil e da região do Contestado, do Espírito Santo e Minas Gerais. Eram as cidades planejadas, que expressavam não só modernas concepções do urbano, mas também a intervenção do Estado do regime autoritário e sua lógica ordenadora do espaço, a da integração do território na espacialidade mediatizada pela renda territorial. Lugares como Ariquemes, em Rondônia. Naquela região, a possibilidade de um adensamento propriamente urbano veio precedida pela destinação agrícola planejada dos projetos de colonização oficial. A cidade já era parte do grande projeto de expansão da fronteira agrícola.

De fato, em poucos anos Ariquemes se tornaria uma cidade de porte médio, com a infraestrutura de uma cidade moderna. Rapidamente se tornou município. Visitei o lugar na fase da derrubada da mata e da construção dos primeiros barracóes de madeira para habitação e casas de comércio. Estive lá em 1975, quando a localidade ainda era uma povoação de casas de madeira, construídas sobre o esboço do que a cidade deveria ser. Mesmo assim, à frente de um barracão de madeira, apertado entre restos de troncos de árvores, uma placa anunciava "Xerox e benzedeira", a combinação de um elemento da mentalidade moderna e urbana com outro elemento de mentalidade tradicional e rústica. Um bom indício da pós-modernidade na floresta secular, uma modernidade de sobreposições e atropelamentos históricos. Visitei-a 
alguns anos depois, em 1982, para uma palestra, quando já se tornara cidade moderna e consolidada. Era nela impossível reconhecer o grande acampamento de sete anos antes. Nenhuma marca sobrara da transição de um momento a outro, como se a cidade tivesse brotado no meio da selva.

A nova Ariquemes foi implantada nas proximidades de um posto telegráfico que o general Cândido Rondon estabelecera na floresta, quando estendia a linha do telégrafo pelo interior do Mato Grosso e do Território do Guaporé, entre 1907 e 1915. Cidade planejada, a dos anos de 1970, para ser uma cidade grande, com largas vias de circulação, nítida separação entre a área comercial e de serviços e a área propriamente residencial. Era e é em tudo a negação da histórica concepção de cidade que nos vem desde o período colonial.

Cada uma dessas concepções de cidade produziu desenhos urbanos diferentes e diferentes mediações no modo de interagir de seus habitantes. De um lado, quanto aos povoados que se tornaram cidades, o desenho interativo informado por uma concepção prática da relação com a natureza. É o caso de Santa Teresinha, no Mato Grosso, e, num primeiro momento, o caso de São Pedro da Água Branca, no Maranhão. De outro lado, o desenho informado por uma visão técnica e, ao mesmo tempo, fantasiosa com a natureza, o que melhor se expressou na proposta de Ariquemes, em Rondônia.

No primeiro grupo, povoados erguidos por populações originadas da roça e dirigidas para a roça. No segundo, a cidade como oposição em relação à roça, como diferenciação e recusa da centralidade do rural, o próprio campo como extensão do urbano.

Naquele momento, na Amazônia Ocidental, a cidade era afirmação positiva de um querer propriamente urbano, uma diferenciação evolutiva e racional da roça, uma sociedade diferençada pelo urbano como polo extremo de uma modalidade de desenvolvimento econômico. Já na Amazônia Oriental, a cidade era meramente residual de um querer comunitário e não urbano. Mais configuração da resistência do antiurbano do que afirmação do urbano. Mais aglomerado espontâneo, desdobramento de uma opção preferencial pela vida agrícola e pelo comunitarismo de aldeia.

O confronto entre essas duas concepções polares de formação de cidades é documental. Expressa um dos aspectos pouquíssimo estudados do que foi o grande conflito social no processo de ocupação da Amazônia nos anos de 1970. Por trás de duas concepções de cidade estava também o conflito entre uma sociedade socialmente determinada pelo trabalho e uma sociedade socialmente determinada pela mercadoria. Essas tipificações são meramente metodológicas e ressaltam apenas as determinações decisivas na constituição e afirmação da mentalidade social.

O que sugere que na Amazônia Ocidental as novas cidades tiveram, desde o início, o urbano como pressuposto de sua estrutura. E que na Amazônia Oriental o urbano 
não esteve nas premissas da ocupação da terra e da formação dos povoados, com uma variante do maior interesse. No Maranhão as populações rurais não gostam de viver esparsas pelo campo, com moradia na própria roça. Preferem viver juntas, em povoados, cultivam ainda o que foi o começo das vilas brasileiras nos séculos XVI e XVII. Ainda assim, esses povoados não são cidades nem deixam de ser germens de cidades historicamente singulares.

Essa dupla e diversa característica de base das condições de surgimento das novas cidades amazônicas no período aqui considerado, na expansão da fronteira, não deixa de se ligar a processos de contraurbanização. Refiro-me à decadência de cidades na trilha de passagem da onda demográfica que se move em direção ao interior do país. Na época de minha pesquisa, era essa a situação da cidade de Pedro Afonso, na confluência do rio do Sono com o rio Tocantins, no então estado de Goiás.

Cheguei lá em 1979 partindo de Fortaleza, passando por Juazeiro do Norte, para seguir o caminho dos romeiros do Padre Cícero em direção à Amazônia. Saíam do Nordeste seco em busca das Bandeiras Verdes, animados por uma profecia atribuída ao Padim Ciço, difundida através de antigo folheto de cordel (para detalhes, ver Vieira, 2001, 2012). Procurei o folheto em vários lugares. Em 1977, fui à biblioteca da Casa de Ruy Barbosa, no Rio de Janeiro, que tem uma grande coleção de "romanços". Conversei com especialistas. Encontrei pelo sertão pessoas que me diziam ter tido em mãos, muitos anos antes, o famoso cordel. No Mato Grosso, encontrei um velho que dizia ter uma cópia manuscrita das profecias. Foi buscá-la para que eu a visse. Guardara-a por dentro da carneira do chapéu. O suor e o tempo transformaram o papel numa pasta. Em São Félix do Araguaia, no Mato Grosso, em meados dos anos de 1970, conheci uma senhora que cantou para mim um bendito da Bandeira Verde, mas ela não tinha o folheto.

Pedro Afonso só se consolidaria como cidade após o desmembramento do norte do estado de Goiás, o território que veio a ser o estado de Tocantins, e após a fundação de sua capital, Palmas, em 1989, situada no interior da nova frente pioneira, foi então que ganhou a característica de cidade. No tempo da pesquisa era pouco mais do que um povoado, com sinais evidentes de decadência. Fora em grande parte um lugar de passagem e um entreposto para as populações que, durante o Estado Novo (1937-1945), se deslocaram do Nordeste para a Amazônia. Pedro Afonso tornou-se o ponto de passagem dos romeiros do Padre Cícero na travessia do rio Tocantins em direção à Amazônia.

Num encontro que tive com romeiros que buscavam as Bandeiras Verdes, em Santa Teresinha, no norte do Mato Grosso, contaram-me que ali onde estavam agora não era o lugar da Bandeira Verde - chegaram e acamparam. Começaram a abrir a mata para fundar um povoado, mas foram reprimidos pela Polícia Militar em virtu- 
de de ação do homem que alegava ser dono daquelas terras. Foram presos. De fato, conversei com eles minutos depois de saírem da cadeia. Os sinais próprios do lugar da profecia não se apresentaram. Estavam de partida, sempre em direção ao Oeste, ao por do sol, como ocorria com os participantes de outros movimentos do gênero.

Esse movimento revestiu de uma mística milenarista os deslocamentos dos participantes da versão popular da chamada Marcha para o Oeste. Nesse sentido, povoados surgiam para serem abandonados, ou mesmo cidades como Pedro Afonso, reduzidas ao temporário das passagens e dos passantes.

Uma mulher idosa, que entrevistei, durante a pesquisa, num povoado da margem esquerda do rio Araguaia, no sul do Pará, vinda com todos os seus acompanhantes do sertão do Ceará, contou-me que migrava porque tivera um sonho. No meio de uma neblina, apareceu-lhe o Padre Cícero, que mandou reunisse o povo e saísse à procura das Bandeiras Verdes, que atravessasse o grande rio. Foi o que fez. Reuniu parentes e vizinhos e iniciou a caminhada. Passou por Pedro Afonso, atravessou o estado do Tocantins, mas logo viu que não era ali. Seguiu adiante e atravessou o outro grande rio, o Araguaia, onde a encontrei. Ela e sua gente tornaram-se posseiros do que entendiam ser terra livre. Mas não estava segura de que fosse ali o lugar da promessa, já disposta a reiniciar a caminhada.

O caso de Pedro Afonso dá sentido à polarização de opostos da Amazônia Oriental e da Amazônia Ocidental, quanto à diversidade das formas urbanas. Muitos povoados e localidades nascidos na lógica da frente de expansão, ao contrário dos da frente pioneira, nasceram como lugares transitórios e temporários para uma população que estava de passagem. Não eram lugares para ficar, os chegantes já estavam de partida. Nesse sentido, não é bom tipificar as novas cidades amazônicas do período aqui considerado. Não são tipos de cidade. Mas, ao lado de verdadeiras cidades, as edificadas para a durabilidade, apoiadas em instituições urbanas e numa mentalidade citadina, surgiram numerosas localidades destinadas a tornarem-se cidades mortas, como outras tantas que tem havido no Nordeste, no próprio Norte e mesmo no Sudeste. 
Referências Bibliográficas

Deffontaines, Pierre. ([1938] 2004), “Como se constituiu no Brasil a rede de cidades”. Trad. O. Valverde. Revista Cientifica Cidades, 1 (1): 119-146.

IAnni, Octavio. (1978), A luta pela terra. Petrópolis, Vozes.

Lefebvre, Henri. (1974), La production de l'espace. Paris, Anthropos.

Martins, José de Souza. (1975), Capitalismo e tradicionalismo. São Paulo, Livraria Pioneira. Martins, José de Souza Martins. (1998), “A vida privada nas áreas de expansão da sociedade Brasileira”. In: NovaIs, Fernando A. \& SCHWARCz, Lilian Moritz (orgs.), História da vida privada no Brasil. São Paulo, Companhia das Letras, vol. 4, pp. 659-726.

Martins, José de Souza. (2014), Fronteira: a degradação do Outro nos confins do humano. 2 ed. São Paulo, Contexto.

Monbeig, Pierre. (1984), Pioneiros e fazendeiros de São Paulo. Trad. A. França e R. E. A. e Silva. São Paulo, Hucitec.

Mounier, Emmanuel. (1964), O personalismo. Trad. João Bénard da Costa. São Paulo, Duas Cidades.

Ribeiro, Darcy. (1970), Os indios e a civilização. Rio de Janeiro, Civilização Brasileira.

Vieira, Maria Antonieta da Costa. (2001), À procura das Bandeiras Verdes: viagem, missão e romaria - movimentos sócio-religiosos na Amazônia Oriental. Campinas, Tese de Doutorado, Universidade Estadual de Campinas.

Vieira, Maria Antonieta da Costa. (2012), “Território em movimento: comunidades camponesas da Amazônia Oriental (Missão de Maria da Praia e Romaria do Padre Cícero)". Revista Pós Ciências Sociais, 9 (18). 
Anexo: Ensaio visual

Nascimento de povoados e cidades na Amazônia Oriental e na Ocidental nos anos de 1970

Fotografias de José de Souza Martins

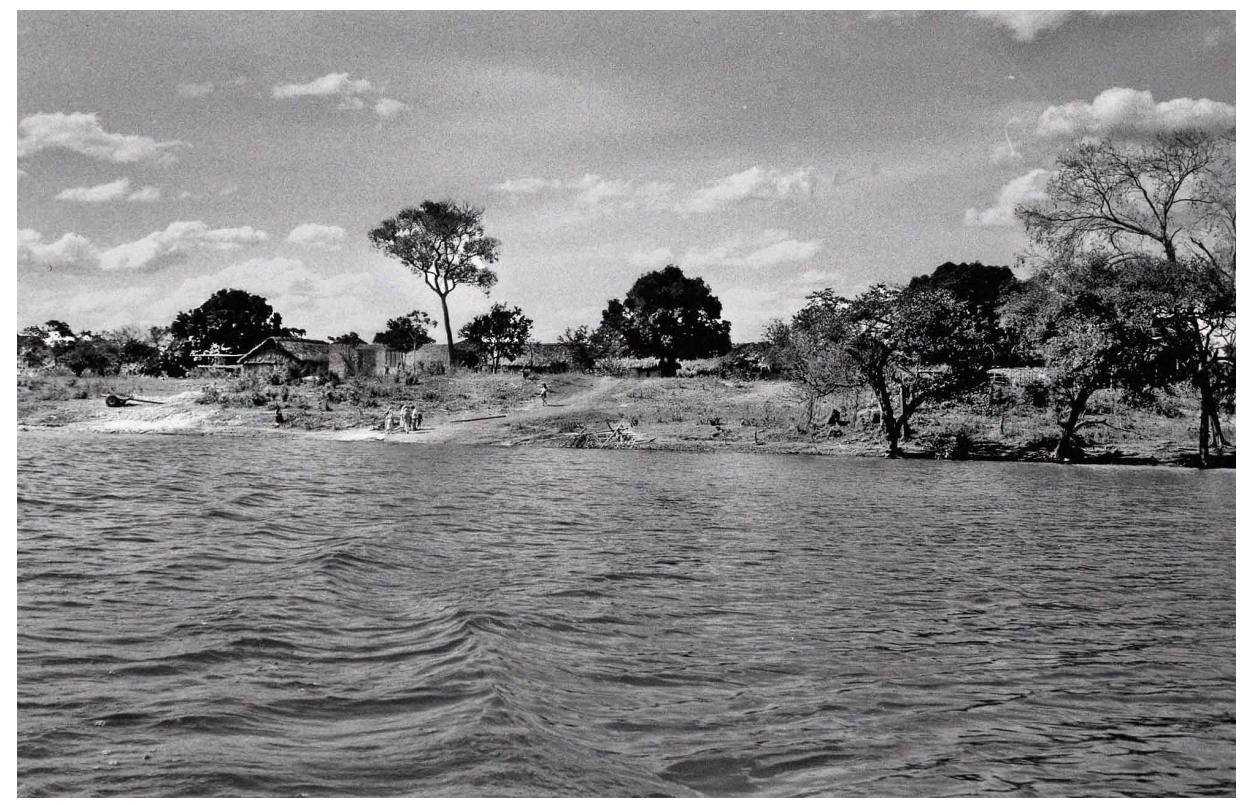

Figura 1: Aldeia tapirapé, margem do rio Tapirapé, norte do Mato Grosso (1976)

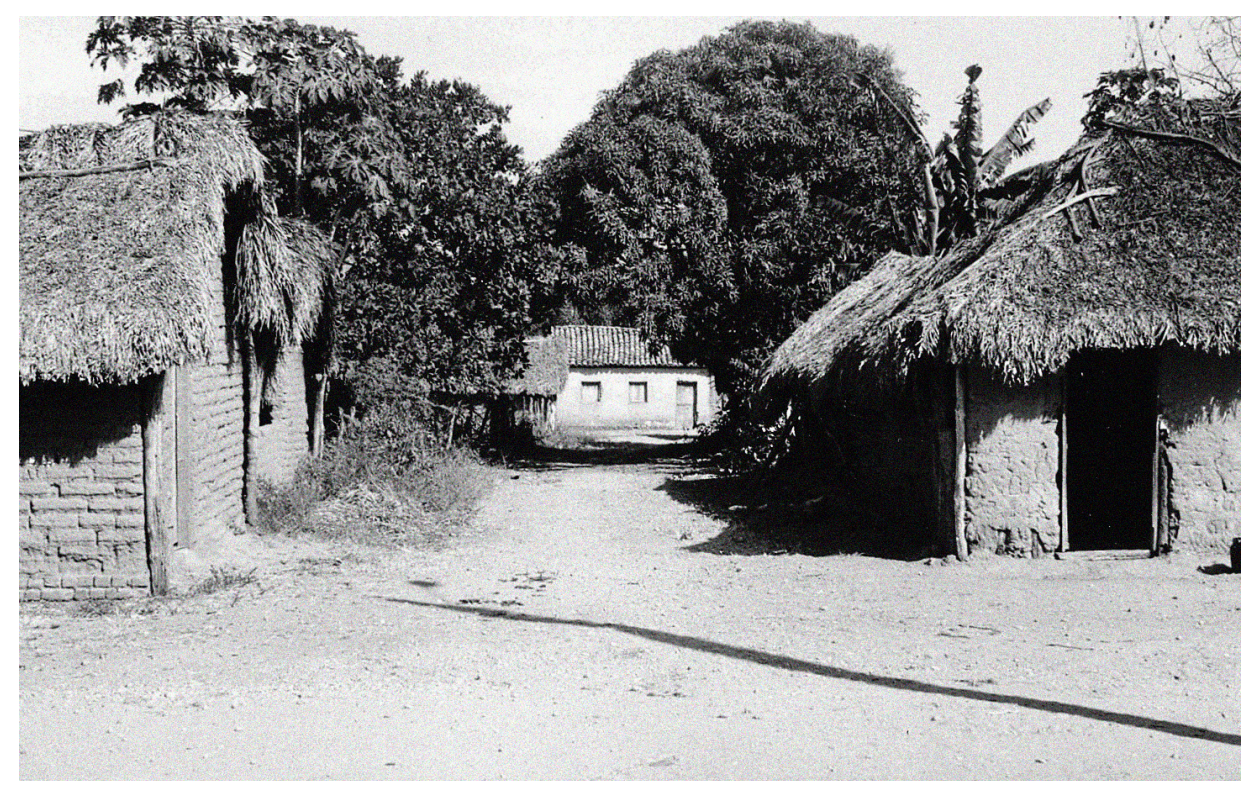

Figura 2: Pedro Afonso, no Estado de Goiás, atual Tocantins, na região da confluência do rio do Sono com o rio Tocantins, na fase da decadência (1979) 


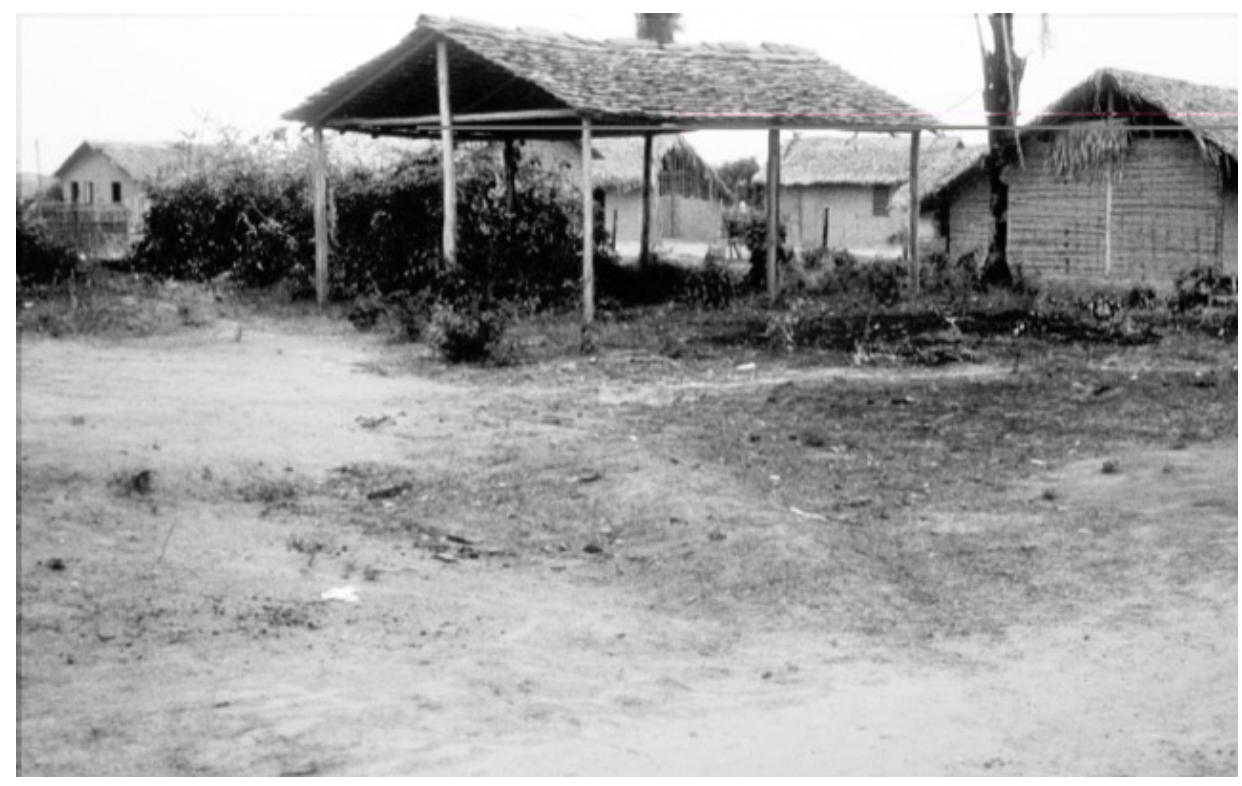

Figura 3: Povoamento espontâneo na frente de expansão do Maranhão. Povoado de São Pedro da Água Branca, na Pré-Amazônia Maranhense (1975)

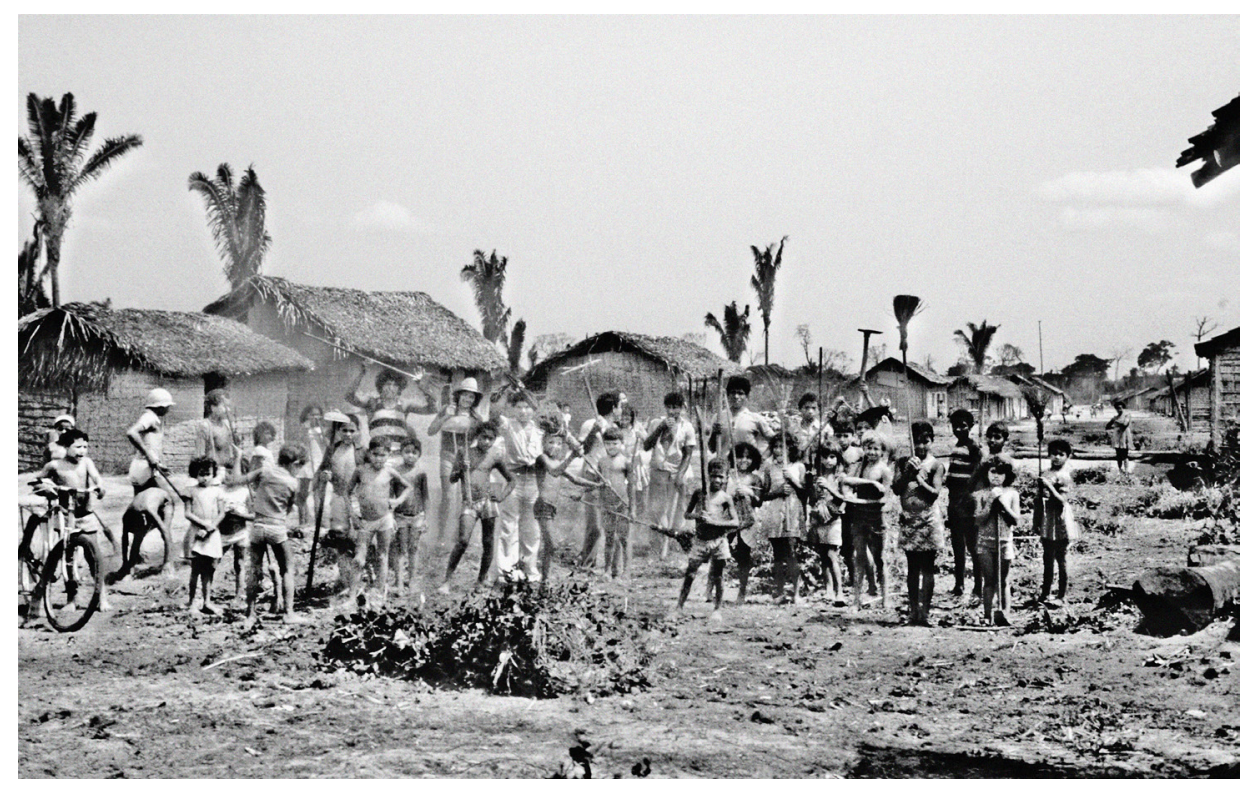

Figura 4: Rua e moradores do povoado de São Pedro da Água Branca, nos primeiros dias (1975) 


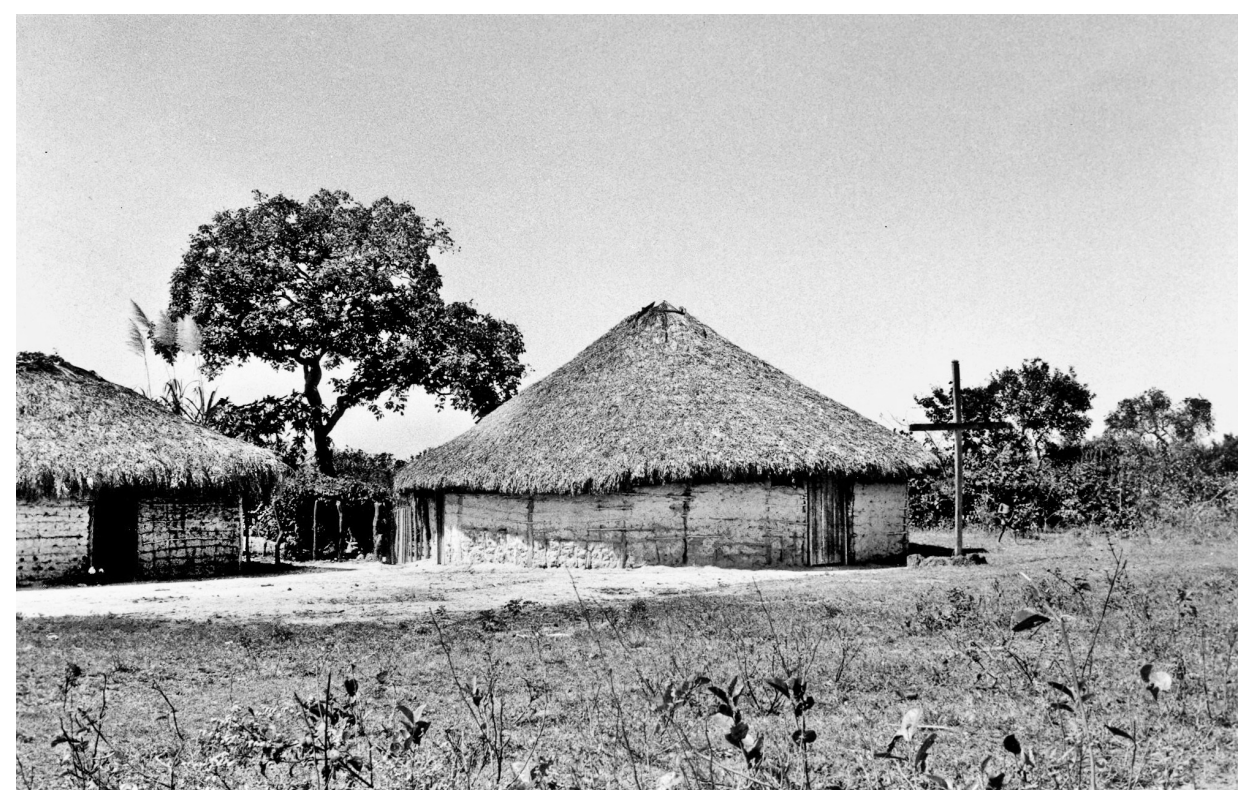

Figura 5: Igreja de estilo românico em pau a pique. Porto Alegre do Norte (MT), região dos rios Tapirapé e Araguaia, ainda um povoado de povoamento espontâneo na frente de expansão (1980)

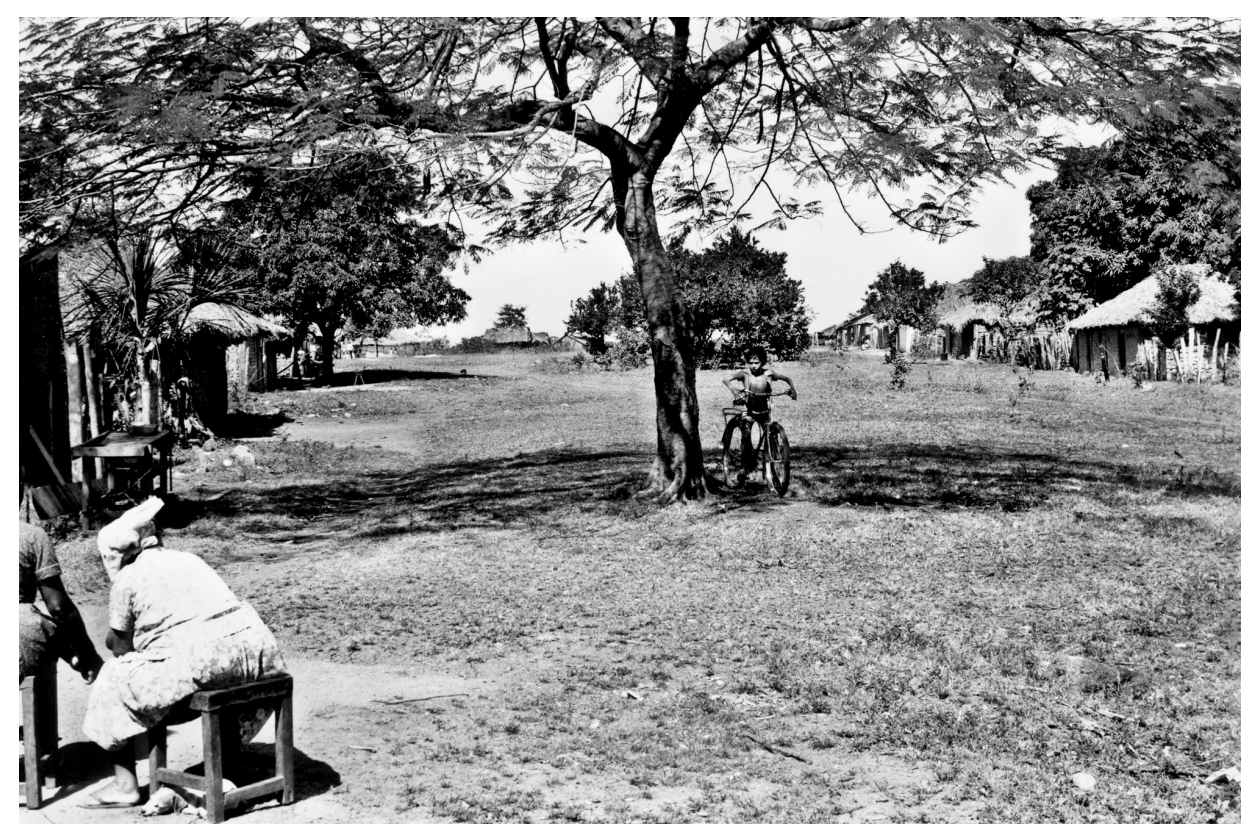

Figura 6: Praça rústica no povoado de Porto Alegre do Norte, Mato Grosso, casas de pau a pique e sapé (1980) 


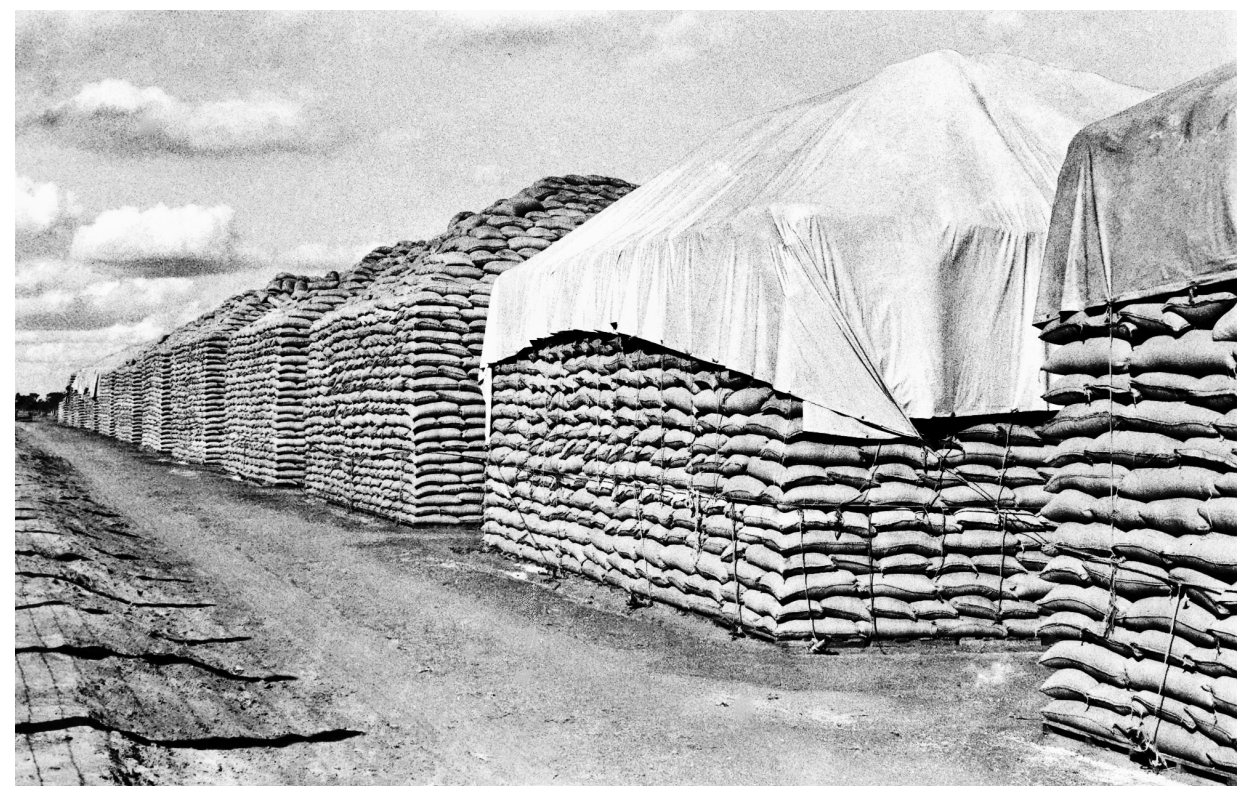

Figura 7: Armazenamento de arroz dos colonos da nascente cidade de Canarana, projeto particular de colonização na frente pioneira do norte do Mato Grosso (1980)

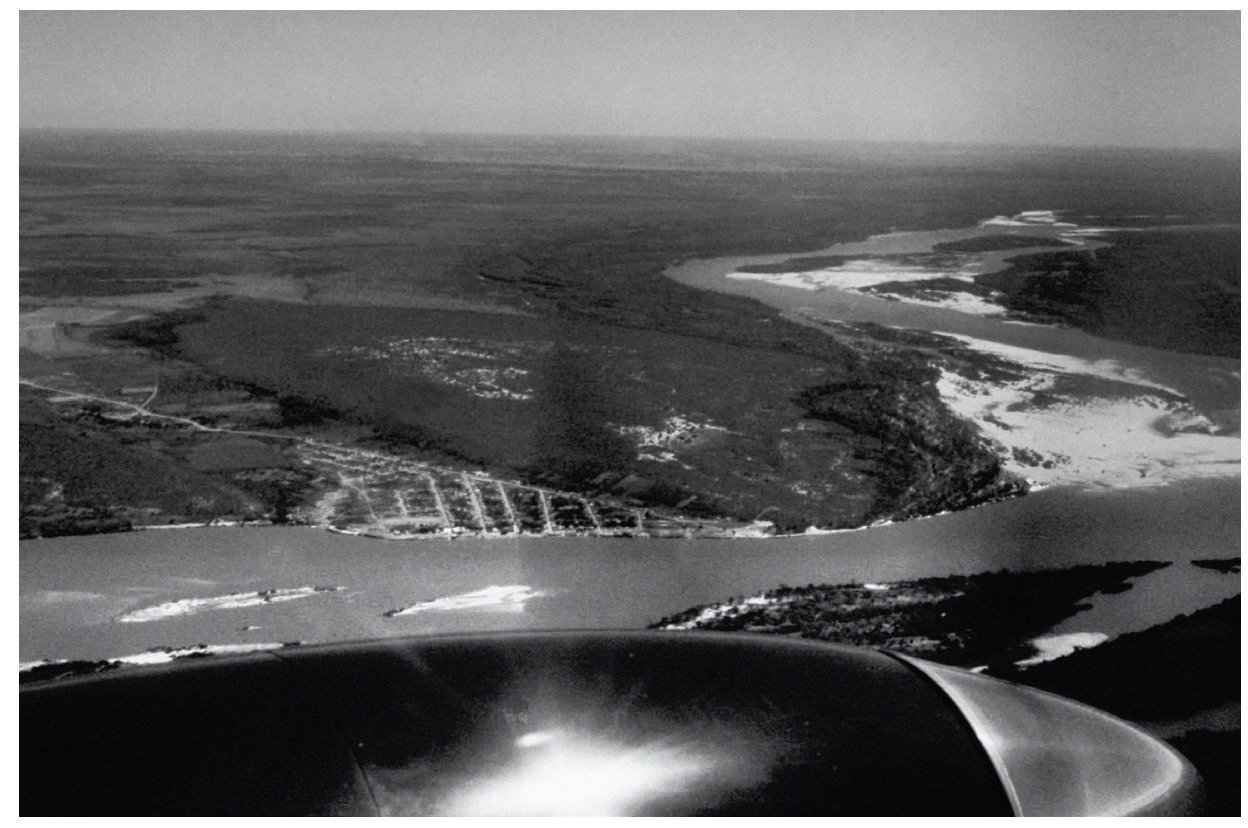

Figura 8: Cidade nascente à margem esquerda do rio Araguaia, norte do Mato Grosso (1977) 


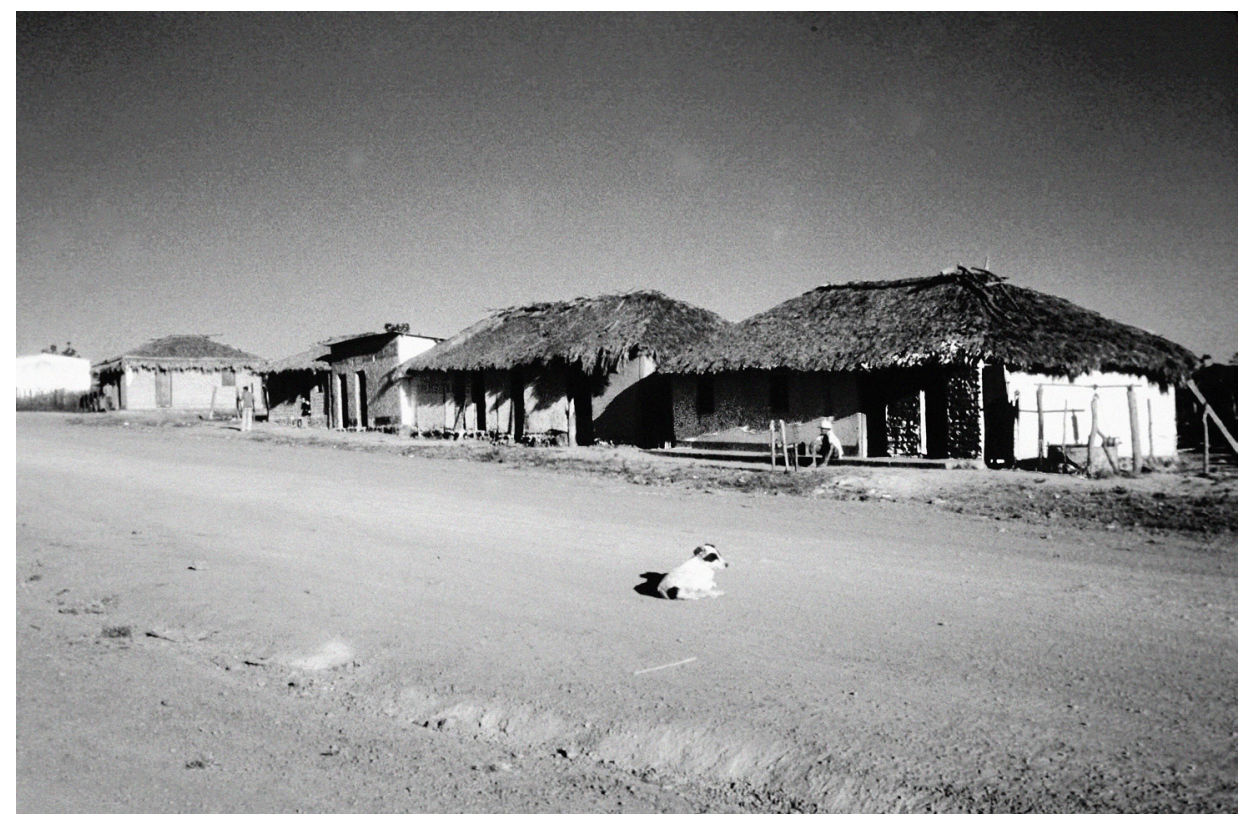

Figura 9: São Félix do Araguaia, norte do Mato Grosso, casas de alvenaria e sapé, cidade situada na sobreposiçãa da frente pioneira com a frente de expansão (1976)

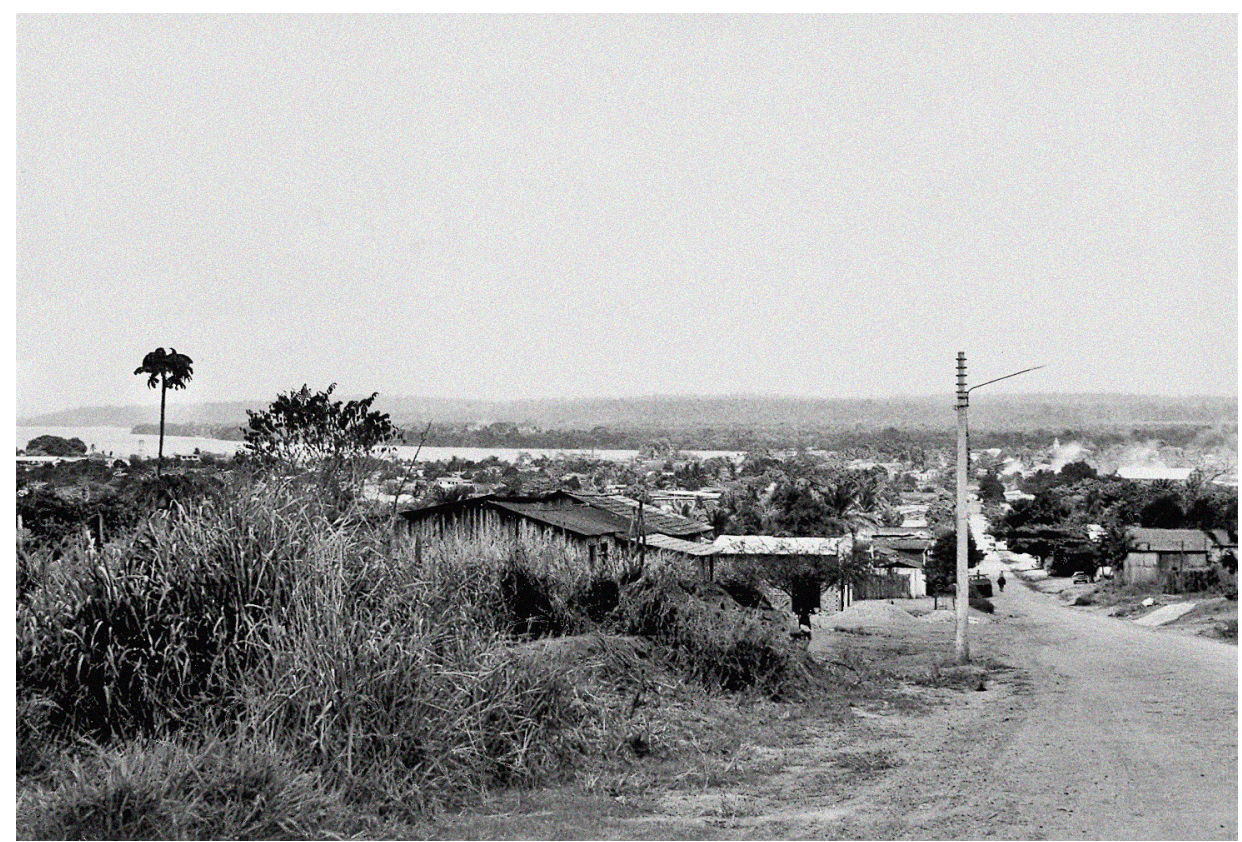

Figura 10: Altamira, cidade da frente pioneira do Estado do Pará, à margem do rio Xingu, atravessada pela rodovia Transamazônica (1985) 


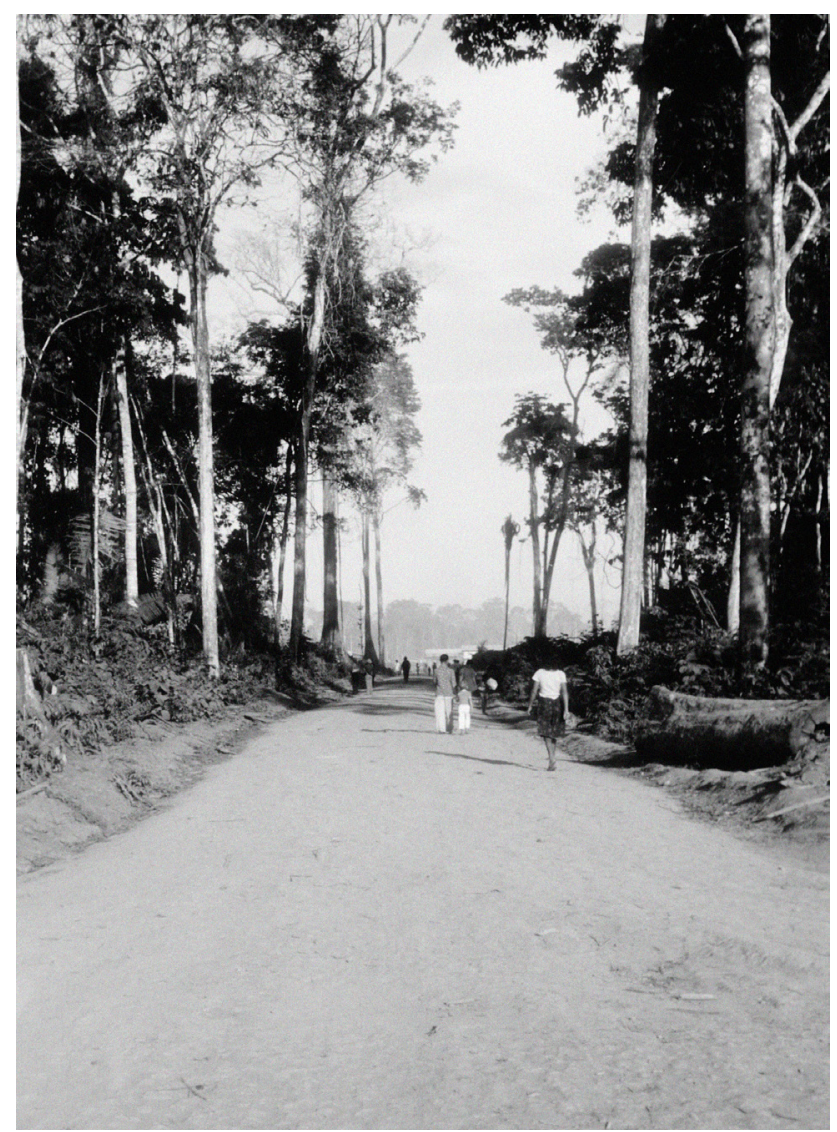

Figura 11: Avenida que separa o bairro comercial do bairro residencial, através da selva remanescente em Nova Ariquemes, cidade nascente na frente pioneira de Rondônia (1977), a pouca distância do antigo posto telegráfico erguido pela Comissão Rondon

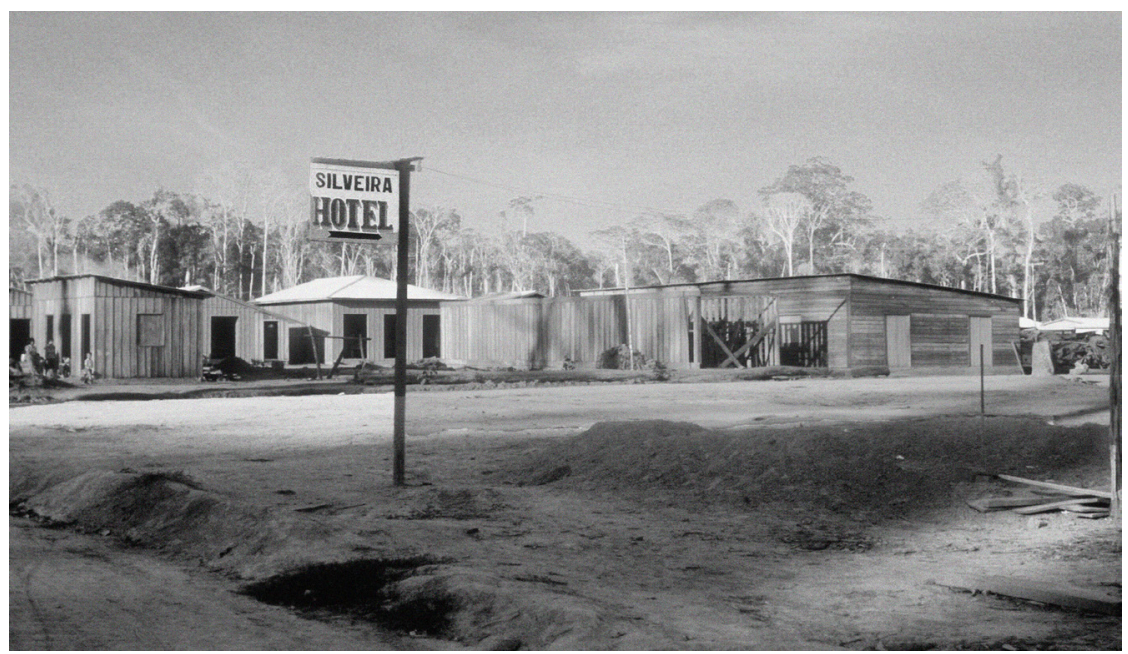

Figura 12: Cidade nascente na selva, na frente pioneira de Rondônia (1977). Casas de madeira e telha 


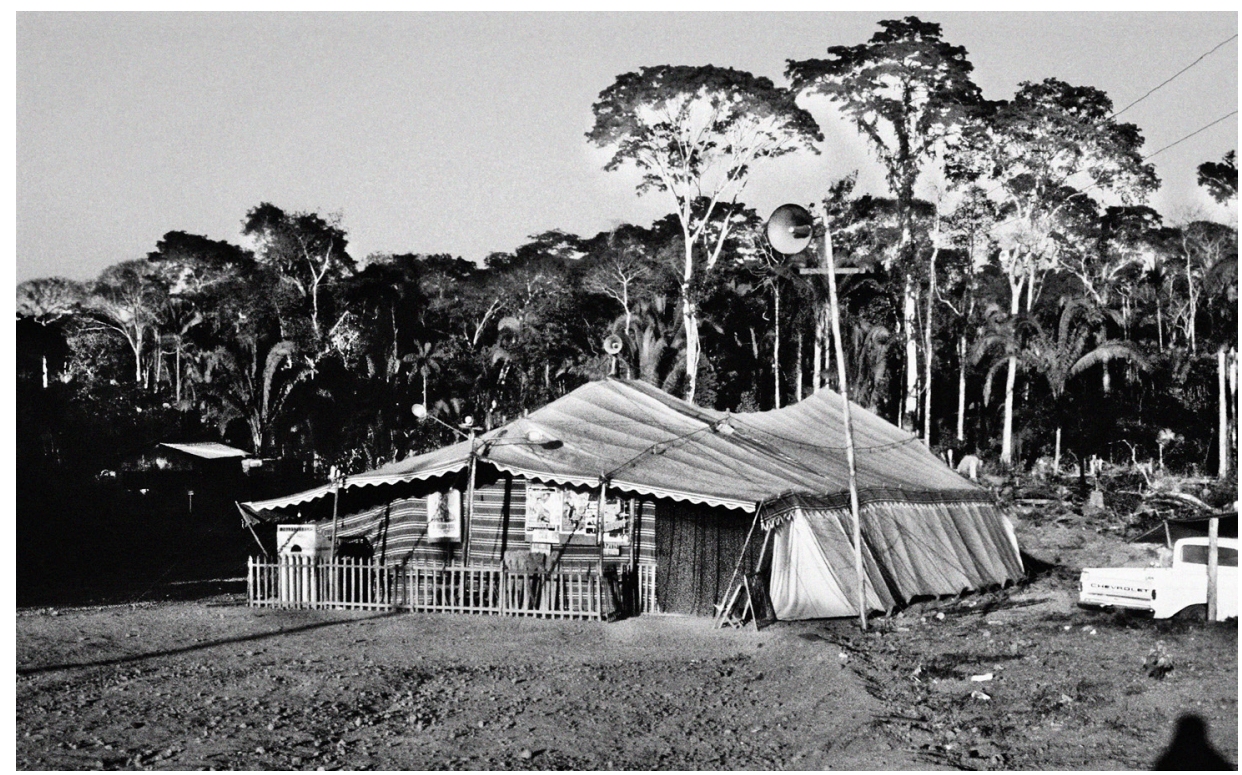

Figura 13: Cinema na selva, à beira de um povoado nascente na frente pioneira da região do rio Jaru, em Rondônia, à beira da rodovia Cuiabá-Porto Velho, em construção (1977)

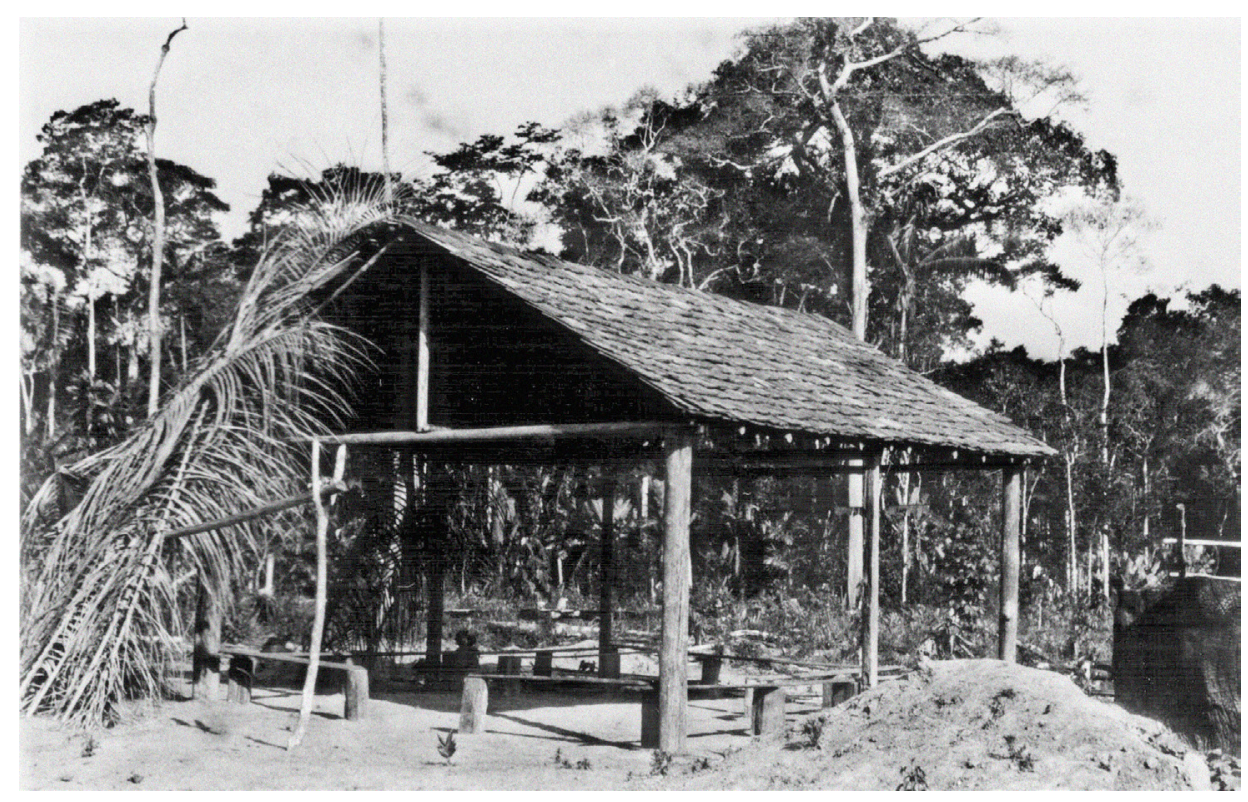

Figura 14: Escola na selva, construída e mantida por povoadores espontâneos da frente de expansão de Rondônia (1977) 


\section{Resumo}

A invenção da cidade na selva

Sintetizo minha pesquisa sobre a fronteira nos anos de 1970 e 1980, quando do violento movimento de ocupação da Amazônia Legal. Cobriu da Pré-Amazônia maranhense ao Pará, Mato Grosso, Goiás, Rondônia e Acre. Polarizo dois grupos de experiências sociais opostas na gestação das cidades e do modo de vida urbano no cenário peculiar. Num extremo, a formação espontânea, a partir de pequenos povoados, decorrente da livre ocupação da terra por migrantes oriundos, em grande parte, do semiárido do Nordeste. No outro extremo, o território ocupado por migrantes do Sul e da região do Contestado do Espírito Santo e Minas Gerais, as cidades planejadas, que expressavam modernas concepções do urbano, na intervenção do Estado ditatorial e sua lógica ordenadora.

Palavras-chave: Fronteira; Frente de expansão; Frente pioneira; Tensões sociais.

\section{Abstract}

The city's reinvention in the jungle

I sum up my research about the border during the 1970s and 1980s, when the Brazilian socalled Legal Amazon was violently occupied. The investigation ranged from the federal state of Maranhão Pre-Amazon to the states of Pará, Mato Grosso, Goiás, Rondônia and Acre. I polarize two groups of opposite social experiences in the framework of the generation of cities and of an urban way of life in this peculiar setting. At one extreme the spontaneous formation, which stemmed from little settlements and the free occupation of land by migrants mostly arriving from the semi-arid region of the Northeast. At another extreme the planned cities, i.e. the territory occupied by migrants arriving from the South and from the Espírito Santo and Minas Gerais region of Contestado. These cities expressed modern conceptions of the urban in the framework of interventions by the dictatorial state, with its ordering logic.

Keywords: Border; Front of expansion; Pioneer front; Social tensions.

Texto recebido em 18/10/2018 e aprovado em 7/11/2018.

DoI: $10.11606 / 0103-2070 . t s .2019 .151225$

JOSÉ DE SOUZA MARTINS é professor titular aposentado de Sociologia da Faculdade de Filosofia, Letras e Ciências Humanas da Universidade de São Paulo. Fellow de Trinity Hall e Professor da Cátedra Simón Bolivar da Universidade de Cambridge (1993-1994), Professor visitante da Universidade da Flórida (1983) e Professor visitante da Universidade de Lisboa (2000). Pesquisador Emérito do CNPq (2019).E-mail: jose38@uol.com.br. 